\title{
Froben Press Editions (1505-1559) in the Holdings of the Centre for Reformation and Renaissance Studies Library: A Brief Survey
}

\author{
VALENTINA SEBASTIANI \\ University of Basel \\ Translated by WENDELL RICKETTS
}

\begin{abstract}
Analysis of the material aspects of books has opened new fields for historical enquiry that connect humanist learning, theology, and the press. The collaboration between Erasmus of Rotterdam and the printers Johannes and Hieronymus Froben of Basel between 1514 and 1536 offers itself as a vantage point from which to observe the making of written culture for humanists, allowing investigations into the media strategies and marketing communication tools employed to produce and disseminate humanist books in early modern Europe. This contribution provides a brief survey of Froben's editions held in the collections of the Centre for Reformation and Renaissance Studies (CRRS) at Victoria University in the University of Toronto. A deep scrutiny of some of the CRRS library's copies sheds light on the technical and economic aspects of Froben's printing activity, while supplying significant information on Erasmus's readership.
\end{abstract}

L'analyse des aspects matériels des livres a initié de nouvelles avenues de recherche historique mettant en lien la formation humaniste, la théologie et les milieux de l'imprimerie et de la publication. La collaboration entre Érasme de Rotterdam et les imprimeurs Johannes et Hieronymus Froben de Bâle entre 1514 et 1536 constitue un cas idéal à partir duquel observer la fabrication de la culture écrite des humanistes, ouvrant la porte à des études des stratégies médiatiques et de la communication de marketing utilisées pour produire et disséminer les livres humanistes en Europe au début des temps modernes. Cet article effectue un survol des éditions de Froben présentes dans les collections $d u$ Centre for Reformation and Renaissance Studies (CRRS) à la Victoria University in the University of Toronto. Un examen minutieux de quelques uns des livres de ces collections met en lumière certains aspects techniques et économiques de l'activité de Froben, et donne également des informations importantes au sujet du lectorat d'Érasme.

\section{Some preliminary considerations for an analysis of the reception and impact of printed works in the early modern age}

ver the past forty years, studies in the history of the book have not
only led scholars to take a closer look at the reading public and at sales 
networks for books, ${ }^{1}$ they have also allowed us to integrate the techniques and descriptive principles of material bibliography into an analysis of the reception and consumption of printed texts and to investigate the socialization of texts in order to shed light upon the methods readers used to assimilate the meanings transmitted by printed books. ${ }^{2}$ Last but not least, interest in paratextual analysis has helped prompt a reevaluation of the book holdings of libraries in Europe, the United States, and Canada, and has stimulated meticulous examination of surviving copies.

The number and calibre of these investigations notwithstanding, ${ }^{3}$ the study of the reception of printed texts, even when clothed as inquiries into the history of the readership, diffusion, or circulation of books, tends to neglect one of the three main investigative axes (production-circulation-reception) of research that have characterized the history of the book since its earliest days. As a result, close analysis of book production has been delegated to disciplines such as analytic bibliography or the study of the history, methods, and techniques of printing. ${ }^{4}$

Analysis of the "book" (in the sense of a material object or merchandise) need not avoid analysis of the "text" (that is, a vehicle for cultural and social meanings). On the contrary, research into the impact of a printed work allows us to reconstruct interrelationships and interconnections among and between a book's production, circulation, and reception. In other words, an analysis of the impact of printed books makes it possible to understand the ways in

1. For a useful appraisal of the history of reading, see Roger Chartier's recent The Author's Hand and the Printer's Mind (Cambridge: Polity Press, 2014). On the commercial circulation of books, see Ian Maclean, Learning and the Market Place: Essays in the History of the Early Modern Book (Leiden and Boston: Brill, 2009).

2. For a view of the sociology of texts that diverges slightly from Donald F. McKenzie's [Bibliography and the Sociology of Texts (Cambridge: Cambridge University Press, 1999)], see Jerome J. McGann, The Textual Condition (Princeton: Princeton University Press, 2001), especially 69-87. Regarding comprehension of the meanings transmitted by printed books, which conceptually modernizes historiographic traditions of the history of reading, see Christian Jacob's "L'art de lire," in Des Alexandries II. Les métamorphoses du lecteur, ed. Christian Jacob (Paris: Bibliothéque Nationale de France 2003), 1-9.

3. Examples include Anthony Grafton, Cardano's Cosmos: The Worlds and Works of a Renaissance Astrologer (Cambridge, MA: Harvard University Press, 1999) and Roger Chartier, Inscrire et effacer: Culture écrite et littérature (XIe-XVIIIe siècle) (Paris: Gallimard, 2005).

4. On the question of fields of inquiry in the history of the book, David Finkelstein and Alistair McCleery's excellent An Introduction to Book History (New York: Routledge, 2005) should suffice. 
which mechanisms for its circulation actually functioned-a focus that the study of the history of the book, precisely because of its epistemological nature, aims to grasp "as a whole, in all its variations over space and time and in all its relations with other economic, social, political, and cultural systems in the surrounding environment." ${ }^{5}$ The richness of such an approach is especially evident in the context of research that is based upon the copies of printed books available for examination in libraries or, increasingly often, in online digital versions. Indeed, traditional bibliological analysis of the formatting, typefaces, pagination, and layouts employed by printing-houses for the production of their texts supplies valuable information regarding the technical and material characteristics of books, whose design and production were clearly linked to their subsequent circulation and to the approval of the public who bought them. In the same way, a critical reading of paratextual elements (introductions, prefaces and afterwords, dedications, summaries, indices, and so forth) sheds light upon specific editorial practices and upon the communications strategies employed by printing-houses to promote the sale of their products. Even an analysis of the illustrations in printed books can reveal clues regarding the economic, commercial, technical, and cultural meanings transmitted by these texts. Finally, meticulous examination of existing copies provides access to information about the uses to which readers actually put their books. Notes, underlinings, acts of censorship, and handwritten marginalia not only help us understand how an owner used and took possession of a book's content; they often also reveal economic and commercial data (where a copy was purchased and at what price, for example), which are a great deal more useful for recent research into the consumption of cultural products. ${ }^{6}$

This brief survey, part of a broader, ongoing inquiry into the impact that the books printed by Johann and Hieronymus Froben between 1491 and 1562

5. Robert Darnton, “What Is the History of Books?” Daedalus 111.3 (1982): 65-83, 67.

6. The bibliography on paratextual analysis is vast. A good starting place: Karl A. E. Enenkel and Wolfgang Neuber, eds., Cognition and the Book: Typologies of Formal Organisation of Knowledge in the Printed Book of the Early Modern Period (Leiden and Boston: Brill, 2005). Regarding the consumption of cultural goods in the modern age, see, for example, John Brewer and Roy Porter, eds., Consumption and the World of Goods (London: Routledge, 1993) and Evelyn S. Welch, Shopping in the Renaissance: Consumer Cultures in Italy 1400-1600 (New Haven: Yale University Press, 2005). 
had on readers at the time, ${ }^{7}$ is situated in precisely this analytical and methodological framework. Specifically, this survey takes as its subject the copies of Froben press editions that are today held in the collections of the library of the Centre for Reformation and Renaissance Studies at Victoria University, University of Toronto.

The majority of the Froben press editions held by the CRRS library come from the lavish collection of Andrew James Bell (1856-1932). A professor at Victoria College and the University of Toronto between 1881 and 1922, Bell assembled some thirty thousand volumes over the course of his life, including 470 items written or edited by Erasmus of Rotterdam and published during the sixteenth and seventeenth centuries. Other copies of Froben press editions are included in the CRRS library's remarkable holdings as a result of its forwardthinking policy of acquiring books on the early modern antiquarian market. Indeed, that approach went hand-in-hand with the strong commitment of the CRRS's founders to the creation of a specialized research institute and library in the field of Reformation and Renaissance studies with a special focus on Erasmus studies. ${ }^{8}$

The library's prize holdings include books published during the course of Erasmus's life and catalogued as "Erasmus Rare." Between 1514 and 1536, some three hundred items, including editions or reprints with Erasmus attributed as author, editor, or translator, were produced by Johann and Hieronymus

7. In the context of the three-year postdoctoral research project (2013-16) that I am conducting at the University of Basel on the cultural and religious impact of Froben press production on sixteenth-century Europe, this study of the copies held by the CRRS library was made possible by a month-long visiting fellowship at the library in May 2013 and by a Konrad Eisenbichler Fellowship. I would like to express my deepest gratitude for the warm reception I received, in particular, from Professors Konrad Eisenbichler, James Estes, Erika Rummel, and Dr. Milton Kooistra of the University of Toronto, Professor Antonio Ricci of the University of York, and Professor Mark Crane of the University of Nipissing. The kindness and helpfulness of Dr. Linda Gail Stone facilitated my study of Froben press editions in the library. I am also deeply grateful to Mrs. Carmen K. Socknat and Mr. Thomas E. Simpson of the Bibliographic Service of the E. J. Pratt Library for their helpful bibliographic advice.

8. On the origins of the CRRS, its library, and Bell and his book collection, see the profile in this issue as well as James M. Estes, The First Forty Years: A Brief History of the Centre for Reformation and Renaissance Studies 1964-2004 (Toronto: Centre for Reformation and Renaissance Studies, 2004), especially 11-24. On the Centre's collection of Erasmiana, see Jacqueline Glomski and Erika Rummel, Annotated Catalogue of Early Editions of Erasmus at the Centre for Reformation and Renaissance Studies, Toronto (Toronto: Centre for Reformation and Renaissance Studies, 1994). 
Froben's printing-house. ${ }^{9}$ Of this considerable production, ${ }^{10}$ the CRRS library owns 180 copies of Erasmus's works printed by the Frobens between 1513 and 1559 (124 works printed by Johann Froben between 1513 and 1527, and fiftysix works printed by his son Hieronymus between 1528 and 1559). As a result, the CRRS library's holdings have the distinction of being one of the largest non-European collections of Froben editions in the world.

\section{Design quality, circulation, and readership of Froben press editions}

Originally from Hammelburg in Franconia, Johann Froben (ca. 1460-1527) moved to Basel toward the mid-1480s and debuted as a printer in 1491 with the publication of an edition of the Bible, the first ever printed in manageable octavo format. In close partnership with printers Johann Amerbach (c. 1440/45-1513) and Johann Petri (1441-1511) and with the celebrated bookseller and publisher Anton Koberger (c. 1440-1513), Johann Froben published some thirty books between 1491 and 1513, including juridical works, texts of devotional and pastoral literature, and several editions of the Bible with commentaries. Most of these were produced in the smaller format if they issued from Froben's own presses but in the more common folio format if they were produced in partnership with Amerbach and Petri. ${ }^{11}$ From among these first Froben editions, the

9. In the absence of a complete catalogue of Erasmus's works-for which see, in any case, Ferdinand Van der Haeghen, Bibliotheca Erasmiana: Répertoire des oeuvres d'Érasme (Nieuwkoop: B. De Graaf, 1972) and Imgard Bezzel, Erasmusdrucke des 16. Jahrhunderts in Bayerischen Bibliotheken: Ein bibliographisches Verzeichnis (Stuttgart: Anton Hiersemann, 1979) - as well as of a full catalogue of works published by the Froben printing-house, the data reported here are taken from The Universal Short Title Catalogue (internet database: www.ustc.ac.uk) and the Verzeichnis der im deutschen Sprachbereich erschienenen Drucke des 16. Jahrhunderts. Hg. von der Bayerischen Staatsbibliothek in München in Verbindung mit der Herzog August Bibliothek in Wolfenbüttel, 25 vols. (Stuttgart: Anton Hiersemann, 1983-2000). Internet database: www.VD16.de.

10. As the VD16 reveals, some four hundred texts by Erasmus were published by Johann and Hieronymus Froben during the course of their careers between 1513 and 1562.

11. Regarding the early years of Froben's career and his book production in that period, see Valentina Sebastiani, "Humanism in Print: Johann Froben's Apprenticeship in Basel (1460-1513)," in Buchkulturen des deutschen Humanismus (1430-1530): Netzwerke und Kristallisationspunkte, ed. Falk Eisenmann and Elke A. Werner (Leiden and Boston: Brill, forthcoming). For a profile of Johann Froben, see Peter G. Bietenholz and Thomas B. Deutscher, eds., Contemporaries of Erasmus: A Biographical Register of the Renaissance and Reformation, 3 vols. (Toronto: University of Toronto Press, 1985-87), 2: 60-63. 
CRRS library owns a copy of St. Augustine's De civitate Dei. ${ }^{12}$ The volume is composed of 353 leaves bound in folio format (but mutilated on the title page and final leaf). The first leaf bears this erroneous indication, in the hand of a careless early cataloguer, of the place and date of the book's printing: "Venetiis 1504." The anonymous annotator's mistake nonetheless allows us to intuit the degree to which the technical and design quality of Froben press editions was, as early as the beginning of the 1500s, comparable to the renowned editorial refinement of Venetian publishers. In fact, the Amerbach-Petri-Froben edition contains an abundant paratextual apparatus, including an illustration of St. Augustine writing that work and a representation of the City of God (Syon) and the Earthly City (Babylon). In addition, it contains a table of contents to facilitate the reader's use of the work. In Roman type and thus distinct from Augustine's text in Gothic script, two short poems and a prefatory letter to the reader by Conrad Leontorius (ca. 1460-1511) also appear. ${ }^{13}$ Leontorius's letter makes clear, among other matters, that the volume represents the seventh of the eleven parts of the edition of St. Augustine's Opera omnia printed between 1505 and 1506 as a joint project of Amerbach, Petri, and Froben.

The Amerbachkorrespondenz-a gold mine of information regarding printing processes, timelines, production costs, and sales techniques for the books produced by the Amerbach-Petri-Froben printing-house-indicates that the complete edition of the works of St. Augustine was published in 1,600 copies for a production cost of just over 3,500 Rhenish florins. ${ }^{14}$

12. Aurelius Augustinus, De civitate Dei, in Aurelius Augustinus, Opera Omnia, 11 parts (Basel: J. Amerbach, J. Petri, J. Froben, 1505-06), part 7. Call number: BR65 A64 1505 Large. The woodcut and Leontorius's poems and letter to the reader appear on ff. a1v-a2r.

13. An early edition of St. Augustine's De civitate Dei with the same illustration, but edited by Sebastian Brant, was printed by Johann Amerbach alone in 1489. See Gesamtkatalog der Wiegendrucke. Hg. von der Kommission für den Gesamtkatalog der Wiegendrucke, 11vols. (Leipzig: Anton Hiersemann, 1925-) (GW). No. 02887. Internet database: www.gesamtkatalogderwiegendrucke.de.

14. Die Amerbachkorrespondenz. Hg. von Alfred Hartman et al., 11 vols., 14 parts (Basel: Verlag der Universitätsbibliothek Basel, 1942-2010), 1: Ep. 306. The letter indicates that Anton Koberger, who commissioned the edition of St. Augustine's Opera omnia published by Johann Amerbach, Johann Petri, and Johann Froben, paid the three printers a total of 7,000 Rhenish florins for the purchase of St. Augustine's Opera omnia, an edition of the Bible with commentaries in six parts, and a reissue of Albrecht von Eyb's Margarita poetica, all three of which had been published in editions of 1,600 copies each. The individual cost of the St. Augustine volumes can be calculated by dividing the total paid by 
The death of his business partners Petri and Amerbach between 1511 and 1513 might have been fatal to Froben's career; however, his surprising technical skill in the art of printing ${ }^{15}$-and, above all, the refined sodalitas of talented scholars that he had assembled around his printing-house along with the favourable conditions for the publishing industry offered by the city of Basel itself-aroused Erasmus's interest in pursuing a fruitful partnership with Froben's venture, bringing both long-lasting prestige and recognition to Froben's printing-house.

The unauthorized 1513 reprint of Erasmus's Adagia, of which the CRRS library owns a copy, ${ }^{16}$ is evidence of the successful attempt of the Froben printing-house to attract Erasmus to Basel. Through the woodcut title border designed by Urs Graf (c.1485-1528)—which depicts the gods Caerus and Nemesis together with a figure representing Humanitas borne in triumph in a cart drawn by Cicero and Virgil on one side and by Homer and Demosthenes on the other-the Froben press demonstrated the design expertise and intellectual refinement that it could offer Erasmus. The copy of this sophisticated visual manifesto that reached Erasmus achieved its desired effect and, in 1514, Erasmus decided to move to Basel. The preparation and printing of Erasmus's works occupied the Froben printing-house almost entirely in the years that followed. ${ }^{17}$

New data made available recently as the result of bibliographical research in digital databases permit the estimate that some five hundred thousand Froben-produced copies of Erasmus's works were in circulation on the

Koberger by the combined number of leaves contained in all three books and then multiplying the result by the number of leaves in Opera omnia alone.

15. As early as 1501, in a dedicatory letter written by the legal scholar Sebastian Brant (1457-1521), one of Johann Froben's closest partners, and included in the edition of the Bible Brant prepared, calls Froben "impressoriae artis insigni[s] chalcograph[us]" (a distinguished chalcographer of the printer's art); see Sebastian Brant, ed., Biblie iampridem renovate, 2 vols., 6 parts (Basel: Johann Petri and Johann Froben, 1502). (Consulted copy: Forschungsbibliothek Gotha, call number: Mon.typ $15022^{\circ}$ 025), f. alv.

16. Erasmus Roterodamus, Adagiorum chiliades tres (Basel: J. Froben, 1513). Call number: PN 6410 E84 1513 Large.

17. For indications regarding the partnership between Erasmus and the Froben printing-house and Urs Graf's title border, see Valentina Sebastiani, "Sous le signe du Kairos: Édition et érudition à Bâle, au service d'Érasme de Rotterdam," in Anne Rolet, ed., Allegorie, Symbole et Dissidence (Antiquité, MoyenÂge, Renaissance) (Rennes: Presses Universitaires de Rennes, 2012), 493-506. 
European market during the first half of the sixteenth century. ${ }^{18}$ As a result of a business structure that was as efficient as it was deeply ramified, books printed in the Froben printing-house quickly reached the major book marketplaces of Europe, including those in Frankfurt, London, Leipzig, Paris, Lyon, and Venice. In addition to providing evidence regarding the extensive circulation of Froben press editions and aiding studies of provenance and readership, many of the copies of Froben press editions of Erasmus's writings in the CRRS library bear information about the books' previous owners, usually on the title border, front cover, or fly-leaf. Most of these were scholars in England, Germany, and the Habsburg Empire. In three cases among these, the owners included contemporaries of Erasmus. Professor of theology Noviomagus (Gerhard Geldenhauer) (1482-1542) owned the CRRS library's copy of In Praise of Folly printed in March 1515; ${ }^{19}$ the copy of Apologiae omnes printed in 1521, moreover, belonged to the Louvain-based humanist Adrian Barland (1486-1538); ${ }^{20}$ and, finally, the library's copy of the 1526 Detectio praestigiarum was owned by the theologian and Catholic reformer Johann Maier von Eck (1486-1543). ${ }^{21}$

The fact that in the early modern age the circulation of books did not end with private ownership is evinced by the CRRS library's copy of a variant of Paraphrasis in Evangelium Matthaei, printed around 1523 in octavo format. The copy belonged to David Kilgerus, first rector of the first Lutheran school in Pressburg (Bratislava) in 1606; some time later, in 1642, the copy passed to the library of the Jesuit College in Augsburg. ${ }^{22}$ The variant held by the CRRS Library (Fig. 1) bears no imprint of date of publication. It can be differentiated

18. For an estimate of the number of copies of Erasmus's works published by the Froben press, see Valentina Sebastiani, "Sales Channels for Bestsellers in Sixteenth Century Europe," in International Exchange in the European Book World, ed. Malcom McLean and Sara K. Barker (Leiden and Boston: Brill, 2015, forthcoming).

19. Erasmus Roterodamus, Moriae Encomium (Basel: J. Froben, 1515). Printed with L. A. Seneca, Ludus de morte Claudii Caesaris; Synesius <of Cyrene>, De laudibus calvitii. Call number: PA 85121515.

20. Erasmus Roterodamus, Apologiae omnes (Basel: J. Froben, 1521). Call number: PA 85011522 Large.

21. Erasmus Roterodamus, Detectio praestigiarum (Basel: J. Froben, 1526). Call number: BV 827 E7 1526.

22. Erasmus Roterodamus, Paraphrasis in Evangelium Matthaei (Basel: J. Froben, c. 1523). Call number: BS 2577 E72 1523a. The following note appears on the fly-leaf: "M[agister] David Kilgerus possidet." On f. a1r, a different hand has added: "Coll[egium] Societat[is] Jesu August[a]nu[m] ad S[anctum] Salvator[em] 1642." For the bibliographic description of the edition, see also VD16 E 2917. 
from the reference edition published in $1523^{23}$ by the woodcut on the title page, which is based upon a metal engraving designed by Hans Holbein the Younger (1497-1543). Consonant with the book's contents and as an additional explication of its message, the engraving depicts, at its lower edge, the fountain of life. Juxtaposed against this image, a skull surrounded by two aged figures (one male and one female) appears at the upper edge. The figures are to be understood as a kind of memento mori for those unable to drink from the waters of life or, more specifically in this case, who failed to gain access to the word of God contained in the book. ${ }^{24}$

The existence of variant editions, especially in the case of works issued or reprinted several times, indicates the title's success on the market. The CRRS library holds additional copies of the many reissues and reprints of Paraphrases on the Gospels produced contemporaneously and in various formats by the Froben press between 1522 and 1524. ${ }^{25}$ Erasmus's correspondence provides some information regarding the large number of copies printed of these volumes. The Paraphrases on the Acts of the Apostles, ${ }^{26}$ for example, was printed in six thousand copies ("3,000 in small type, 3,000 in large type"). ${ }^{27}$ Here, it is worth noting that the rapid publication of a small-format version allowed Erasmus to take advantage of the services of a courier on his way from Basel to Rome to quickly send a complimentary copy to Pope Clement VII (1478-1534), to whom he had dedicated the work; in return, Erasmus received a donation of money as a sign of the pope's appreciation. Erasmus also sent a rebound copy of the Parafrasis on St. John to Ferdinand I (1503-64), to whom the work had been dedicated, ${ }^{28}$ receiving a gift of money in exchange on that occasion as well. ${ }^{29}$

23. For a full bibliographic description, see VD16 E 2916.

24. For an interpretation of the title page woodcut and its use in various other Froben-press editions, see Basler Buchillustration 1500-1545. Hg. von Frank Hieronymus (Basel: Verlag der Universitätsbibliothek, 1984), 376-77, no. 366.

25. Glomsky and Rummel, 88-92, No. 379-82, 384-87, 389, 391, 394, 396, 398-400, 402-03.

26. Erasmus Roterodamus, Paraphrasis in acta apostolorum (Basel: J. Froben, 1524). Call number: BS 2577 E72 1524b.

27. Desiderius, Erasmus, Opus epistolarum, Percy S. Allen et al., eds. 12 vols. (Oxford: Clarendon, 1906-58), 5: Ep. 1423. (This work will henceforth be referred to as Allen.)

28. Desiderius Erasmus, Paraphrasis in evangelium secundum Joannem (Basel: J. Froben, 1523). Call number: BS 2577 E72 1522c.

29. Allen 5: Ep. 1376. 
We know, finally, that the printer's supply of the edition of the Paraphrases on the Acts of the Apostles - available for sale beginning at the end of February 1524-was exhausted by the end of April of the following year. ${ }^{30}$

That Froben press editions sold quickly is demonstrated as well by one of some forty editions, including reissues and reprints that appeared during Erasmus's life, of his best-known and most widely sold work, In Praise of Folly. ${ }^{31}$ The CRRS library owns, in fact, a copy of a quick reprint of In Praise of Folly (Fig. 2) ${ }^{32}$ that was produced after the first Froben edition of March 1515 was nearly exhausted in just over three weeks. ${ }^{33}$ In the first Froben March edition of 1515, moreover, Erasmus's text has an autonomous signature collation (A-X4), separated from that adopted for the other texts included in the same edition. ${ }^{34}$ This fact provides evidence of the extent to which the Froben printing-house was certain of future sales of Erasmus's work and, therefore, its ability to circulate on its own. This is the case, in fact, with the CRRS library's copy, ${ }^{35}$ which contains Erasmus's work detached from the other texts in the edition originally printed by Froben. Of additional interest is the handwritten marginalia on the title page of the library's copy in which the previous owner, Professor Noviomagus, seems to comment critically on Erasmus's text (Fig. 3). ${ }^{36}$

In addition to bookplates that identify individual readers, other elements of these editions shed light on the kinds of clients the Froben press had in mind for the sale of its books. The sumptuous illustrations and iconography employed in the printing of quite a number of editions of Erasmus's works, for

\section{Allen 5: Ep. 1414 intro.}

31. A list of editions of In Praise of Folly is presented in Van der Haeghen, 122-23.

32. Erasmus Roterodamus, Moriae Encomium (Basel: J. Froben, ca. 1515). Printed with L. A. Seneca, Ludus de morte Claudii Caesaris; Synesius < of Cyrene>, De laudibus calvitii; Erasmus Roterodamus, Letter to Dorp. Call number: PA 8512 1515c.

33. References to the rapid sale of the March 1515 edition can be found in Beatus Rhenanus's letter to Erasmus of 17 April 1515; see Allen 2: Ep. 328.

34. The March 1515 edition of In Praise of Folly contains as well L. A. Seneca, Ludis de morte Claudii Caesaris, and Synesius < of Cyrene>, De laudibus calvitii. The signature collation of this edition is: a-h4 A-X4

35. Call number: PA 85121515.

36. Noviomagus left this comment on Erasmus's text on f. A1r: "Turpe, non putavam" (Indecent, I did not think so), adding laconically at the end of the printed title, "fiat voluntas tua d[omi]ne Ihesu" (Thy will be done, Lord Jesus). 
example, are evidence of the Frobens' desire to appeal to the tastes of a refined, select community of scholars in the European Republic of Letters of the early modern age. These learned men were capable not only of appreciating the ornamental quality of the images, but also of grasping the complementary meanings brought to the texts by illustrations. This was the case with the ArminiusApelles title-page woodcut border created by Ambrosius Holbein (1494-1519) in 1517 and used, among others, for the 1522 edition of Erasmus's Annotations to the New Testament. ${ }^{37}$ On its upper edge, the border (Fig. 4) depicts a scene from the Battle of the Teutoburg Forest showing the victory of Arminius over the Roman army and, at the lower edge, a scene from Lucian of Samosata's description of Apelles's Calumny. ${ }^{38}$ The border may allude, on the one hand, to the theological polemic that Erasmus's first (1516) and second (1519) editions of the New Testament had provoked and, on the other, to the political and religious implications of Erasmus's interpretations of sacred texts. ${ }^{39}$ Finally, the notes left occasionally by readers regarding the price paid for their copies are of utmost importance for understanding the social standing and spending capacity of the purchasers of books produced by the Frobens. An annotation on the title page of the library's copy of the 1543 reissue of Erasmus's Colloquia, for example, indicates that it was purchased at the Basel market in 1586 for ten Assis (i.e., 60 Kreuzer, or 1 Goldgulden) (Fig. 5). ${ }^{40}$ In the context of the history of the consumption of cultural goods in the Renaissance, a statement of the worth of Froben editions in circulation on the European market is meaningful to the extent that their value can be compared to the cost of other goods or when oscillations in the price of the Frobens' books can be grasped over time. ${ }^{41}$

37. In Novum Testamentum ... Annotationes, ed. Erasmus Roterodamus (Basel: J. Froben, 1522). Call number: BS 2335 E7 1522 Large.

38. For a detailed description of the title-page woodcut border, see Basler Buchillustration 1500-1545, 246-50, no. 259.

39. For an interpretation of the title border, see Silvana Seidel Menchi, "Erasmus as Arminius-Basel as the Anti-Rome? Closed and Open Circles of Humanist Communication," Archiv für Reformationsgeschichte /Archive for Reformation History 99 (2008): 66-95.

40. Erasmus Roterodamus, Familiarum colloquiorum (Basel: H. Froben, N. Episcopium, 1543). Call number: PA 8506 1543. On f. a1r: "Anno 1586 Emptus Basileae 10. Assibus."

41. For an overview of the cost of living and of currency values, see Mark Häberlein, The Fuggers of Augsburg: Pursuing Wealth and Honor in Renaissance Germany (Charlottesville: University of Virginia Press, 2012), especially 8, 31-98. 
In 1527, following the death of its founder, the Froben press passed into the hands of Johann's son, Hieronymus (1501-63). ${ }^{42}$ The printing-house's ongoing activity meant continuity in the production of Erasmus's works even after his own death in 1536. Of the hundreds of titles by Erasmus that Hieronymus Froben printed between 1528 and 1562, in association with Johann Herwagen (1497-1558) and, later, Nicolaus Episcopius (1501-64), the CRRS library's cata$\log$ lists fifty-six. Although the quality of Hieronymus Froben's editions continued to distinguish him in the context of book production of his day, the observer cannot help but note a significant reduction in both technical and design innovations, especially evident in the number and quality of paratextual elements with respect to earlier years. In the editions produced by Hieronymus, for example, title-page woodcut borders and other illustrations are often absent; in addition, his work recycled the historiated woodcut initials used by his father in the $1520 \mathrm{~s}$ and standardized and simplified the printer's mark. ${ }^{43}$ The copies of Hieronymus Froben editions in the CRRS library contain much more sporadic marginalia left by previous owners or, in some cases, handwritten annotations that have been partially erased or blocked out. ${ }^{44}$ Especially conspicuous are the multiple acts of censorship visible in the texts, which seem to serve nearly as counterpoint to the absence of marks identifying the reader and are evidence of the transformation of the cultural and spiritual climate in which Erasmus's works appeared in Europe beginning in the second half of the sixteenth century. ${ }^{45}$ On the copy of

42. For information regarding Hieronymus Froben, see Bietenholz and Deutscher, 2: 58-60.

43. See, for example, the historiated initial that depicts Brutus's murder of Caesar in Erasmus Roterodamus, Enarratio pia iuxta ac docta in Psalmum XXXIII (Basel: H. Froben, 1531), 5. Call number: BS 1450 33rd E7 1531; and the standard printer's mark in Erasmus Roterodamus, Epistolarum opus (Basel: H. Froben, N. Episcopius, 1558), f. a1r. Call number: PA 8511 A2 1558.

44. See for example, Erasmus Roterodamus, Adagiorum Chiliades (Basel: H. Froben, N. Episcopius, 1551). Call number: PN 6410 E84 1551 Large; on p. 1, an only partially successful attempt has been made to block out the phrase "sum Godefredo."

45. On the censorship of Erasmus's works by the Catholic Church through its Index librorum prohibitorum et expurgatorum (regarding which, see Index des livres interdits. J. M. De Bujanda, Francis M. Higman, and James K. Farge, eds., 11 vols. [Québec: Editions de l'Université de Sherbrooke / Genève: Librairie Droz, 1985-2002]), the literature is vast. J. M. De Bujanda's "Erasme dans les index des livres interdits," in Langage et Vérité. Études offertes à Jean-Claude Margolin, ed. Jean Céard (Genève: Librairie Droz, 1993), 31-47 should suffice here. 
the 1538 edition of St. Ambrosius's Opera omnia, ${ }^{46}$ for example, Erasmus's "advice to the reader" in the third volume, as well as other paratextual indications regarding his editorial work, was censored with pigmented blocks, occasionally framed within decorative floral borders (Figs. 6, 7). Surprisingly, finally, a copy of a 1535 reissue of the Novum Testamentum was censored by an unknown reader who blocked out the name and attributes of Pope Leo X (Figs. 8, 9). ${ }^{47}$

If elements such as these provide a further example of the quality of information that can be discerned about readers from handwritten annotations or marginalia, when taken together-as this brief examination of copies held by the CRRS library suggests - they contribute to the argument that the choices made by the Froben printing-house, frequently under the supervision of Erasmus himself, were not unrelated to the number and variety of readers into whose hands the Frobens' volumes found their way. Beginning with the phases of their design and manufacture, the Froben press editions that flooded the early modern European market were intended to open a direct line of communication with the press's readers. Whether that dialogue was initiated through choices regarding format, foliation, the size of print runs, or the design of title borders, it expanded as a function of the degree to which the message of the text was considered explosive. Thus, the large number of editiones principes, of reissues and reprints, or of examples of variant editions conserved at the CRRS library are fundamental to a reconstruction of the material, visual, economic, and cultural strategies employed by Johann and Hieronymus Froben's printing-house for the production, circulation, and appropriation by readers of Erasmus's most popular titles in early modern Europe.

46. Ambrosius, Opera omnia, ed. Erasmus Roterodamus (Basel: H. Froben, 1538). Call number: BR 65 A3 1538 Large.

47. Novum Testamentum, ed. Erasmus Roterodamus (Basel: H. Froben, 1535). Call number: BS 1990 1535 Large. 


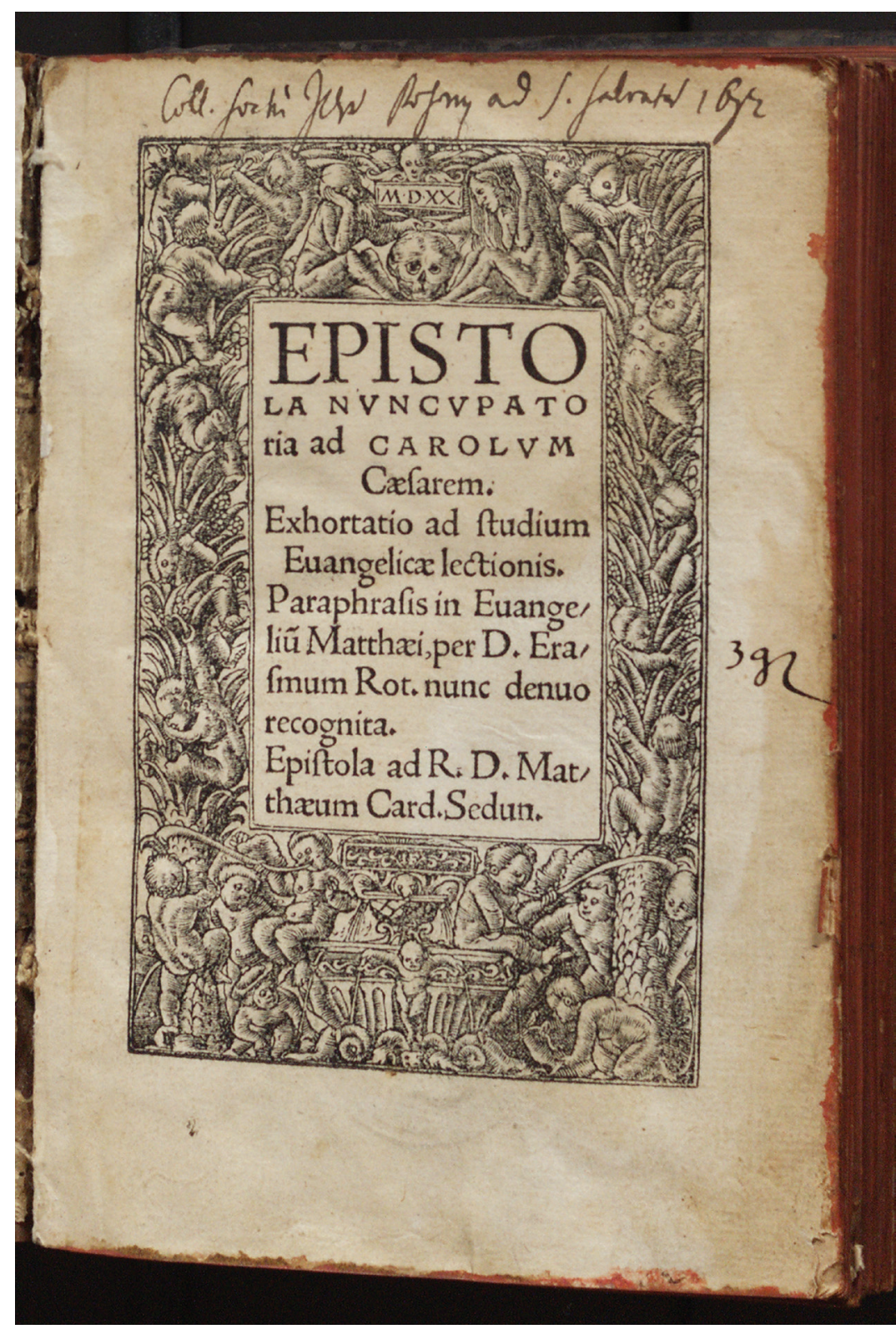

Fig. 1. Erasmus Roterodamus, Paraphrasis in Evangelium Matthaei (Basel: J. Froben, 1523). CRRS Library, Erasmus Rare: BS2577 E72 1523a. F. a1 recto. 


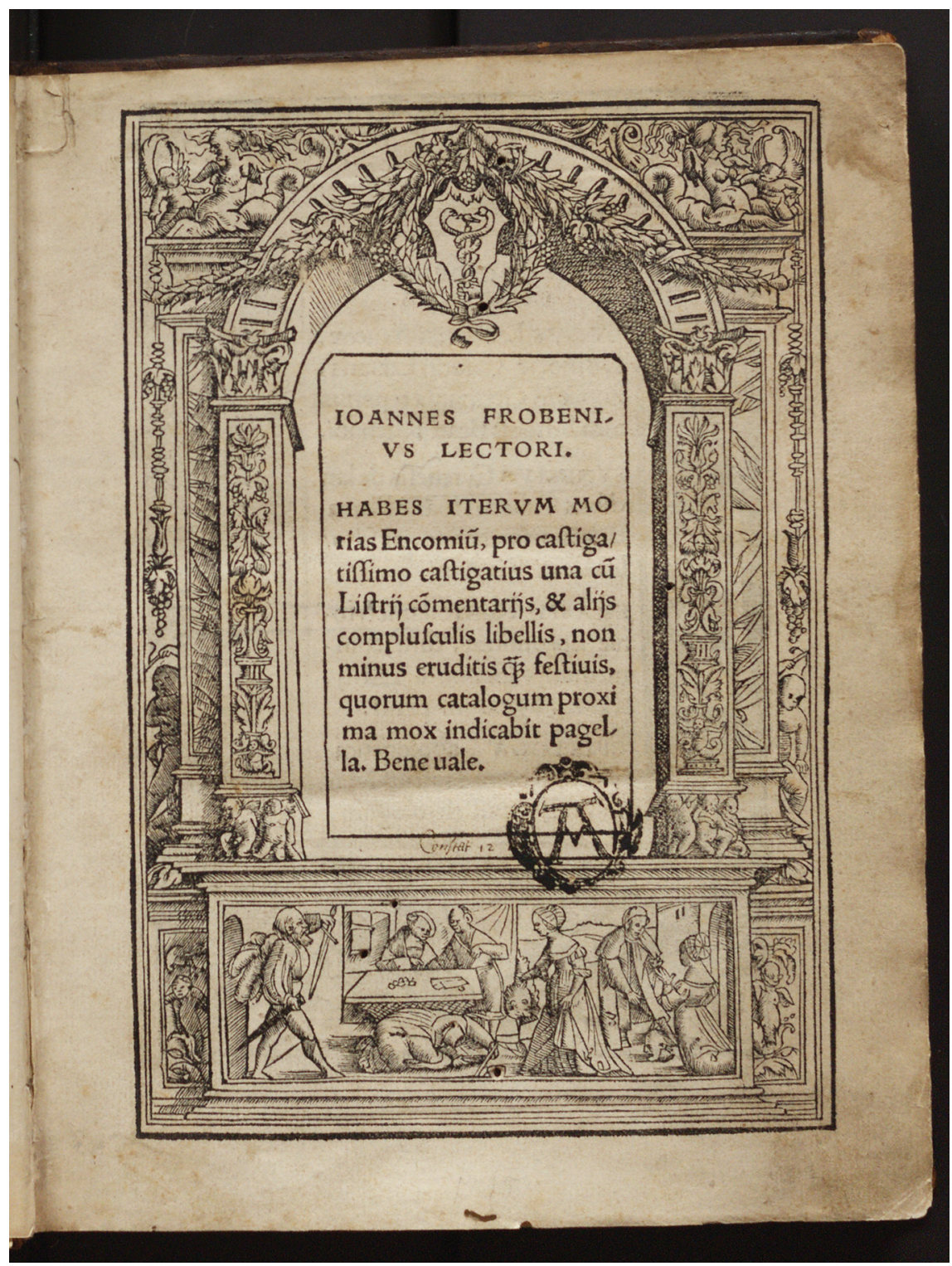

Fig. 2. Erasmus Roterodamus, Encomium Moriae (Basel: J. Froben, 1515?). Printed with Lucius A. Seneca, Ludus de morte Claudii Caesaris; Synesius <of Cyrene>, De laudibus calvitii; Erasmus Roterodamus, Letter to Dorp. CRRS Library, Erasmus Rare: PA 8512 1515c. F. al recto. 


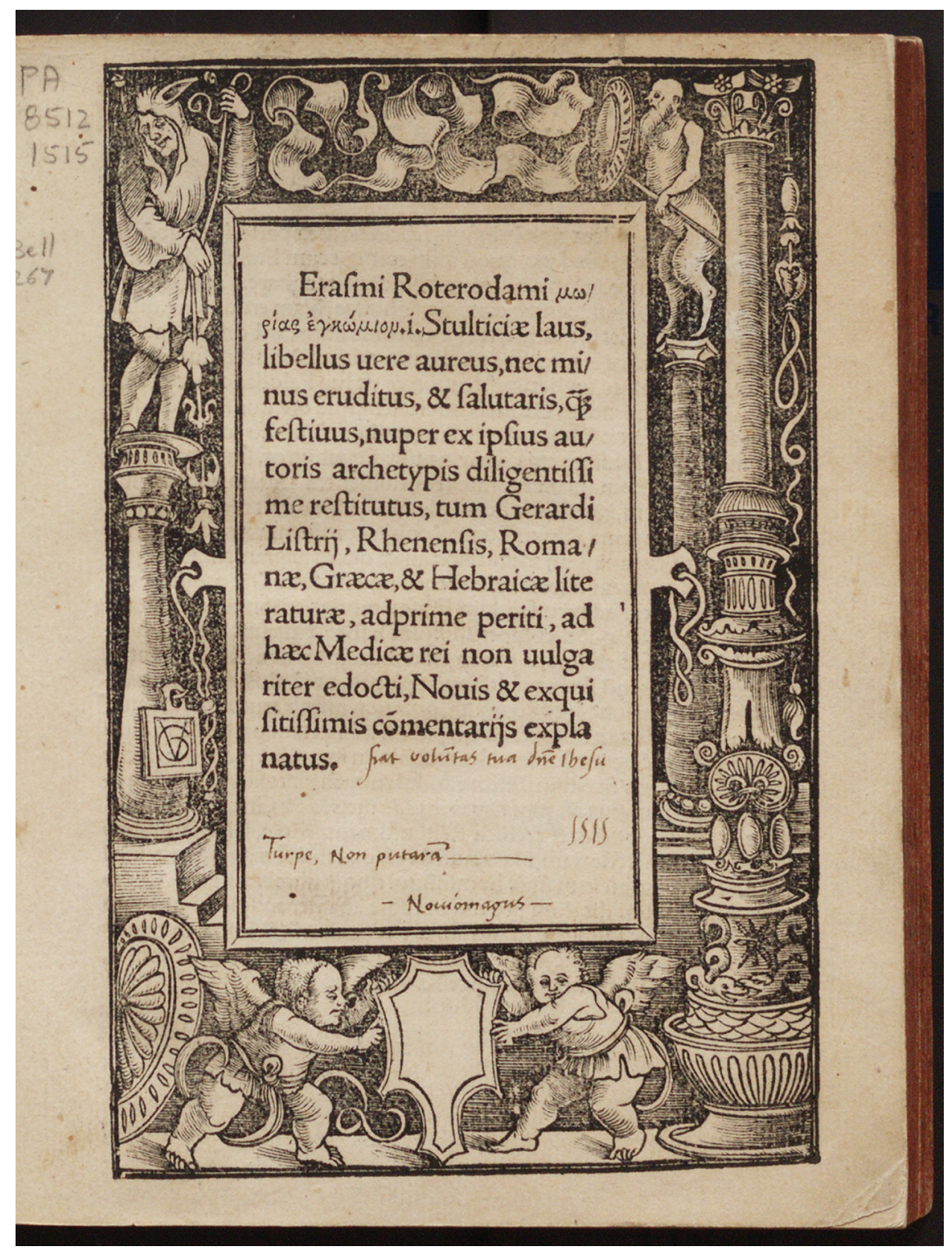

Fig. 3. Erasmus Roterodamus, Moriae Encomium (Basel: J. Froben, 1515). Printed with Lucius A. Seneca, Ludus de morte Claudii Caesaris; Synesius < of Cyrene>, De laudibus calvitii. CRRS Library, Erasmus Rare: PA 8512 1515. F. A1 recto. 


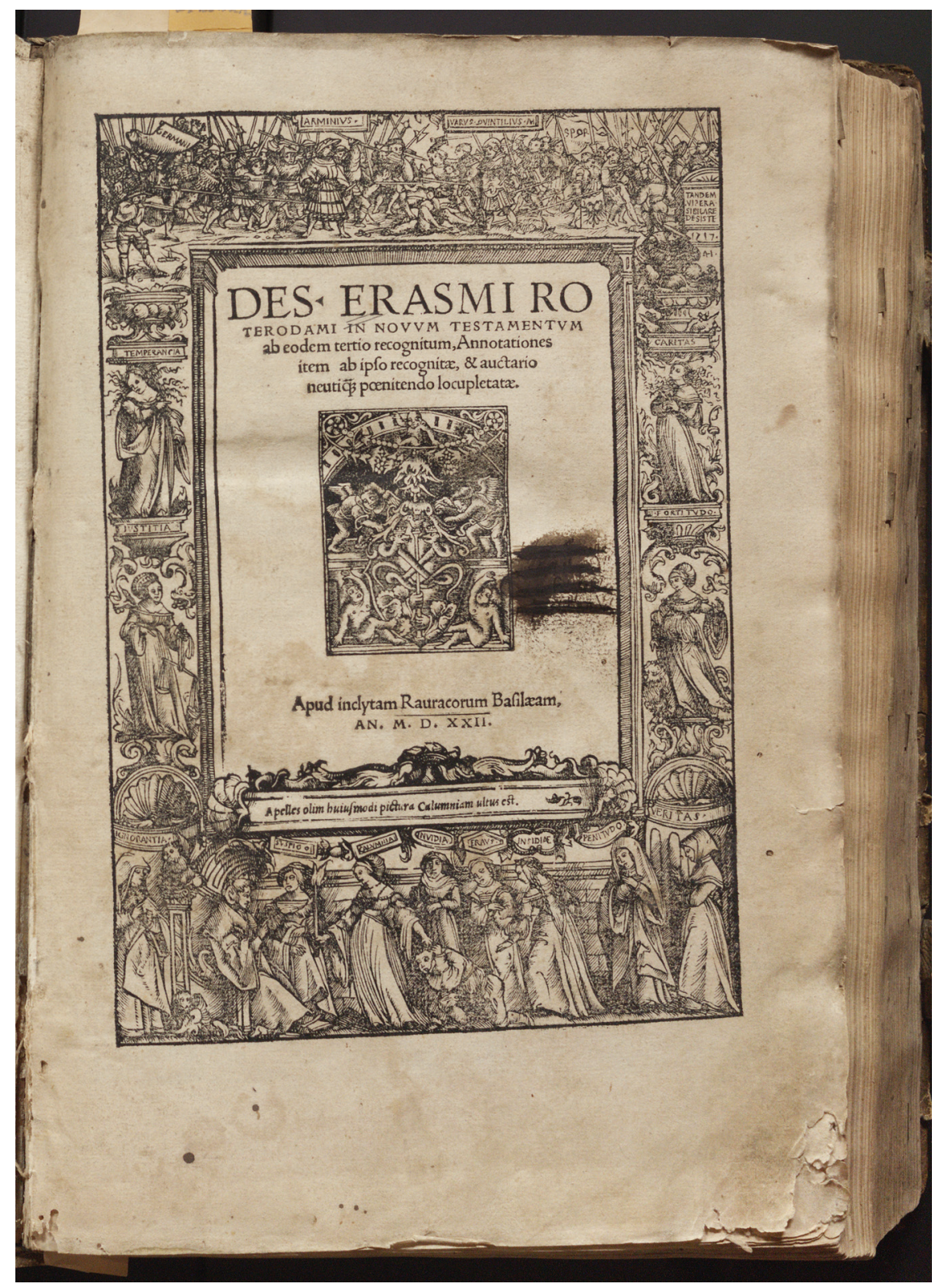

Fig. 4. In Novum Testamentum ... Annotationes, ed. Erasmus Roterodamus (Basel: J. Froben, 1522). CRRS Library, Erasmus Rare: BS 2335 E7 1522. F. a(a)1 recto. 


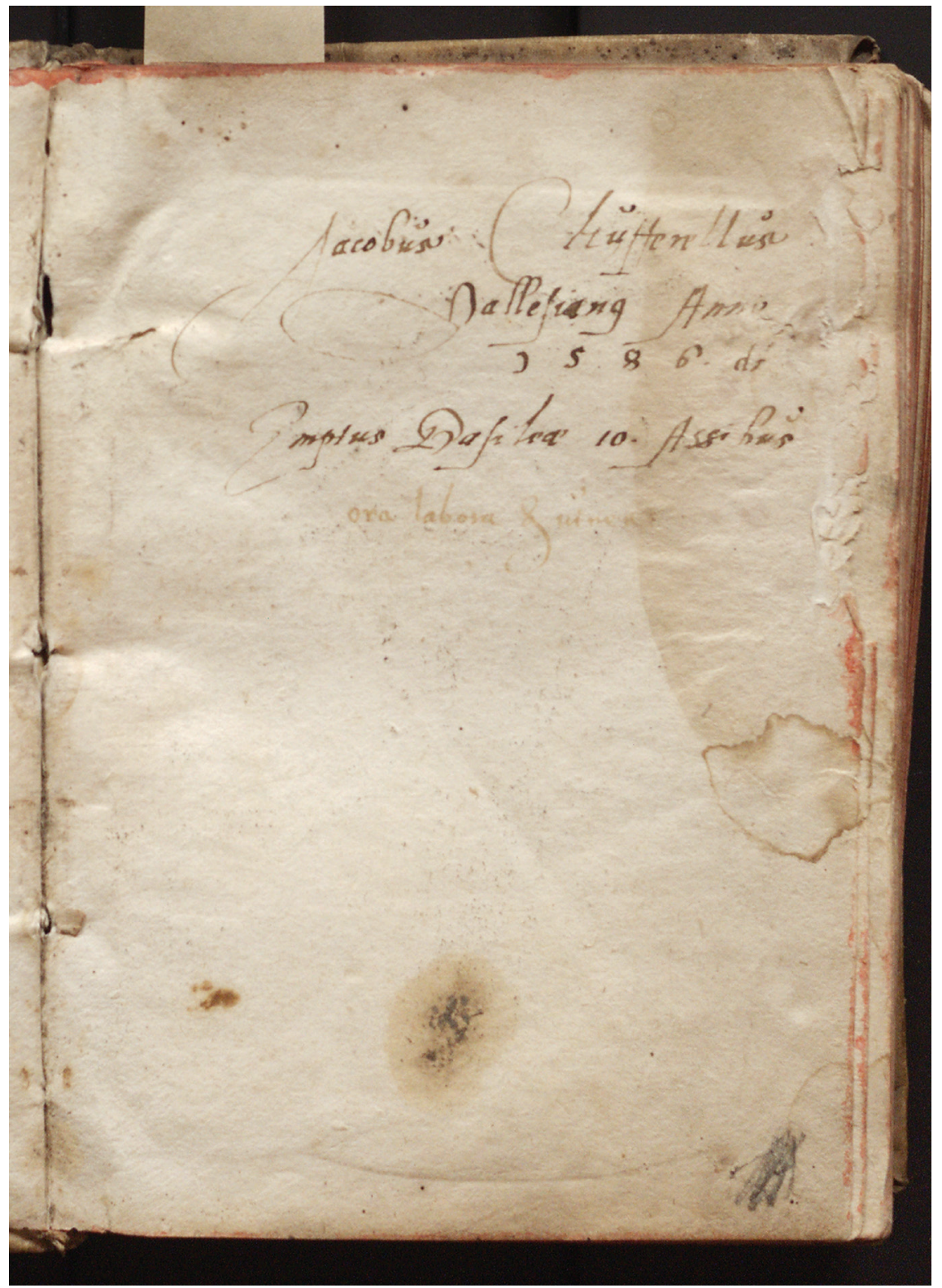

Fig. 5. Erasmus Roterodamus, Familiarum colloquiorum (Basel: H. Froben, N. Episcopium, 1543). CRRS Library, Erasmus Rare: PA 8506 1543. Fly-leaf. 


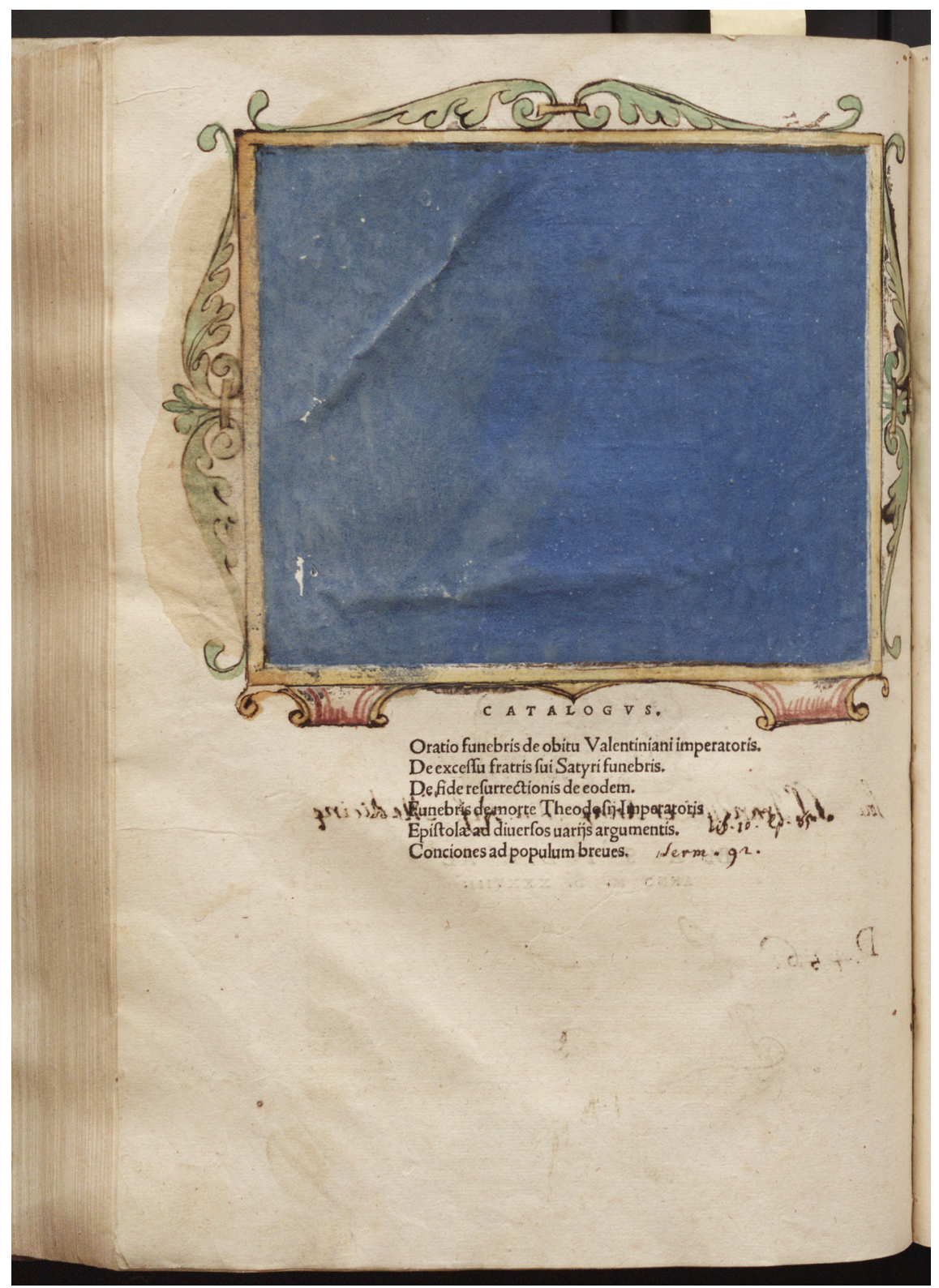

Fig. 6. Ambrosius, Opera omnia, ed. Erasmus Roterodamus (Basel: H. Froben, 1538). CRRS Library, Erasmus Rare: BR 65 A3 1538. Vol. 3, p. 2. 


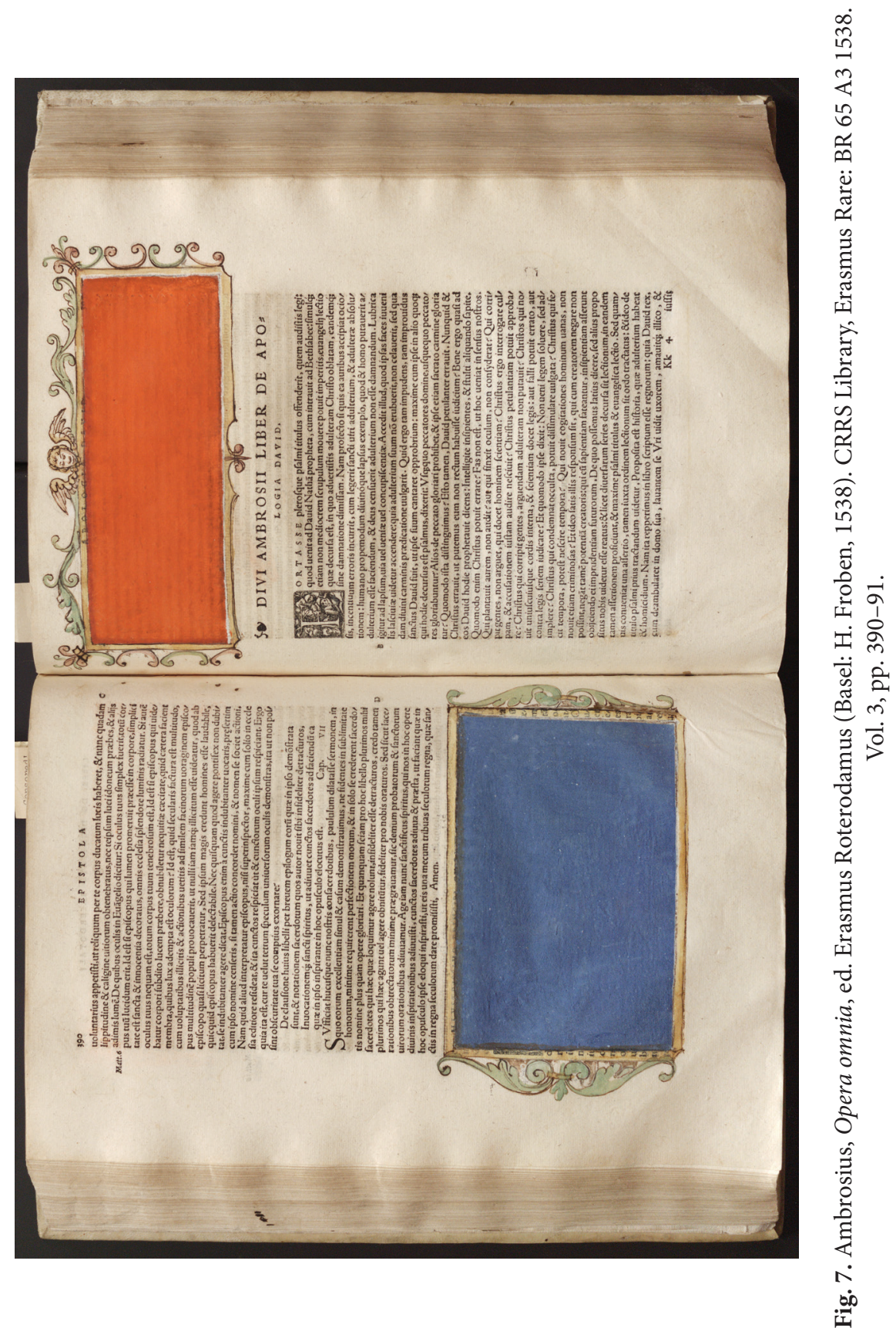




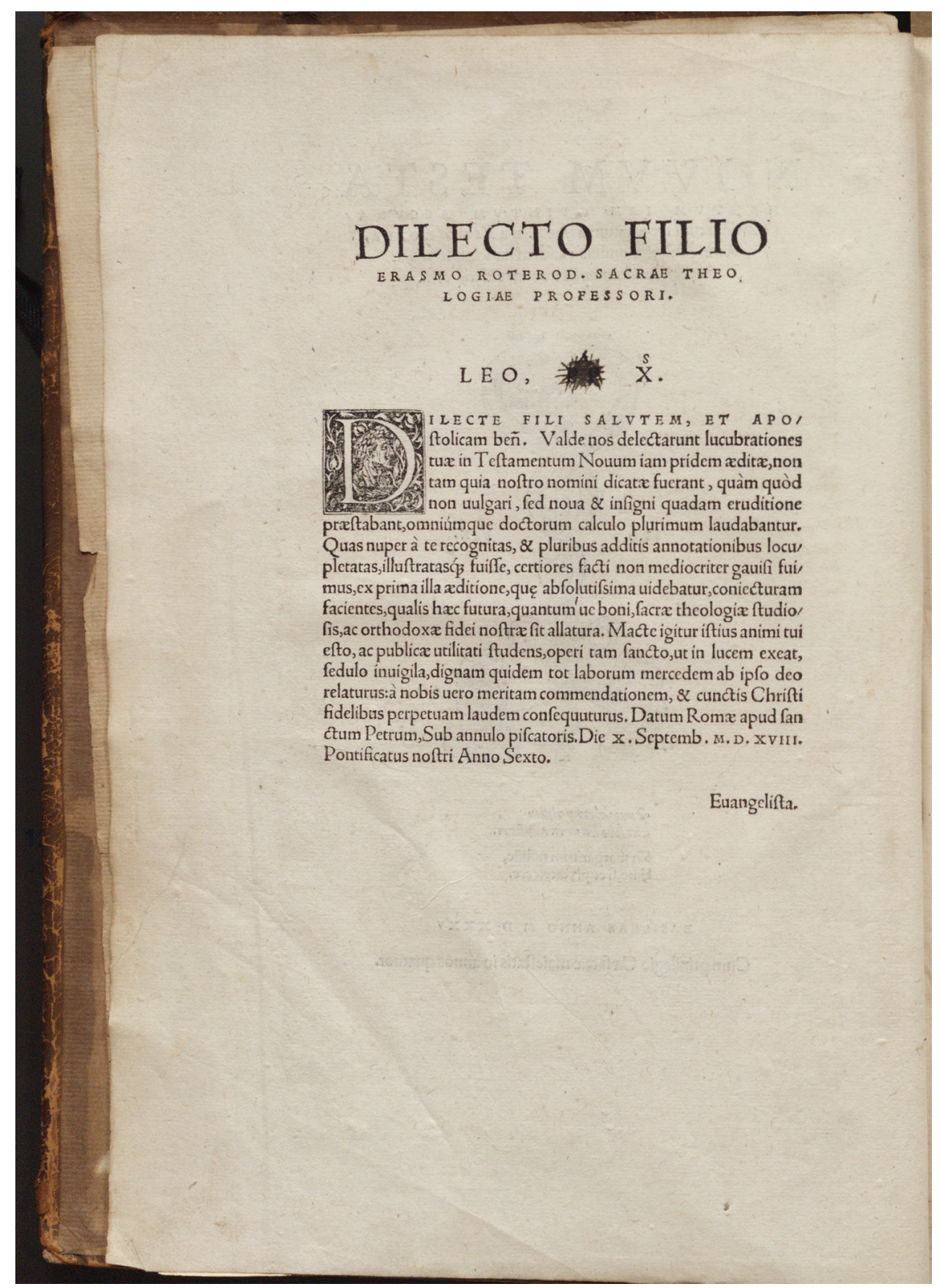

Fig. 8. Novum Testamentum, ed. Erasmus Roterodamus (Basel: H. Froben, 1535). CRRS Library, Erasmus Rare: BS 1990 1535. F. al verso. 


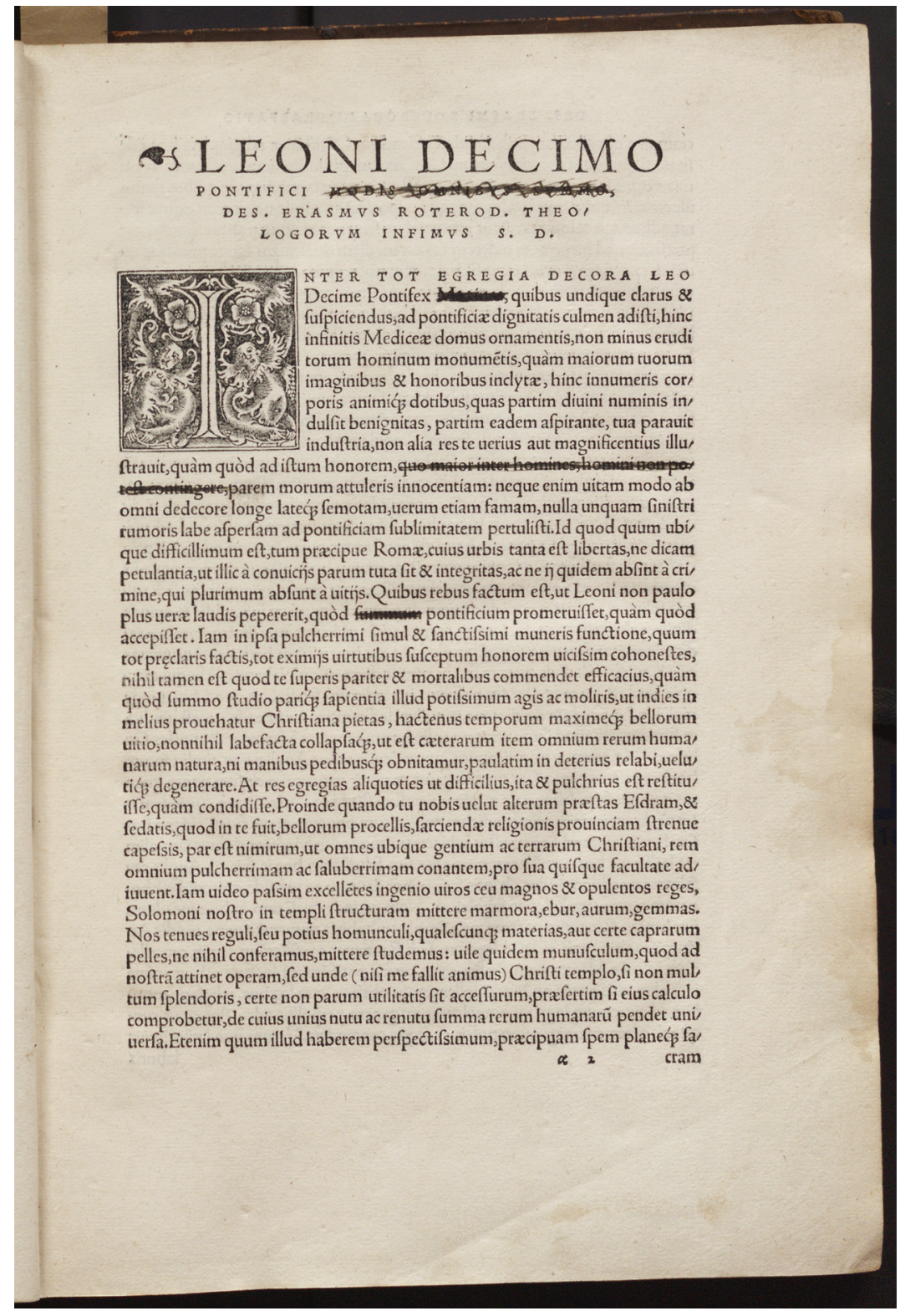

Fig. 9. Novum Testamentum, ed. Erasmus Roterodamus (Basel: H. Froben, 1535). CRRS Library, Erasmus Rare: BS 1990 1535. F. a2 recto. 